\title{
UNDERSTANDING THE BEHAVIOUR OF OIL-DEGRADING MICRO-ORGANISMS TO ENHANCE THE MICROBIAL REMEDIATION OF SPILLED PETROLEUM
}

\author{
MACAULAY, B.M.* \\ Natural Resources Institute, University of Greenwich, Medway campus, \\ ME4 4TB, Chatham Maritime, Kent, United Kingdom \\ (phone: +44757488-5638; +2347062731106) \\ *Corresponding author \\ e-mail: babajidemacaulay@gmail.com \\ (Received 26 $6^{\text {th }}$ Sept 2013; accepted $14^{\text {th }}$ Aug 2014)
}

\begin{abstract}
Petroleum-contamination of both terrestrial and marine environments have persisted as a result of the increasing demand on liquid petroleum globally which has led to the need to clean up spilled petroleum using eco-friendly methods. Of all the petroleum-cleaning techniques explored, the use of petroleum-degrading microbes has received most attention. The microbial remediation of spilled petroleum has been proved to be cost-effective, eco-friendly and sustainable. However, these microbes have been found to thrive under certain environmental/nutritional conditions which influence their behaviour towards spilled petroleum. This study aims to identify the factors responsible for the change in behaviour of oil-degrading microbes which might help facilitate better petroleum spill management. Some of these factors include: the physical nature of the spilled petroleum; chemical nature of the spilled petroleum; availability of nutrients; water temperature; concentration of oxygen; soil region/soil particle size; competition from other micro-organisms. Petroleum-degrading microbes were also found to degrade specific hydrocarbon components in liquid petroleum due to the specific metabolic pathway utilized by individual microbes. This makes the use of a microbial consortium a more aggressive option for the microbial degradation of spilled petroleum than the use of microbial isolates. However, more research on the factors influencing theabundance and productivity of oil-degrading anaerobes may need to be carried out. Also, how oil-degrading microbes can be aided to break down asphalthenes should be investigated.
\end{abstract}

Keywords: microbial remediation, biodegradation, oil-degrading microbes, spilled petroleum, oil spillclean-up.

\section{Introduction}

\section{Oil spill incidence and accidents}

Every year, an average of about 35 million barrels of petroleum is transported across the seas around the world and this renders the marine ecosystem vulnerable to pollution (Anisuddin et al., 2005). Between 1996 and 1999, an average of 407 oil spills occurred annually in Alaska (Poland et al., 2003). A UNDP (2006) study reports that approximately 273 oil spills have occurred annually in Nigeria between 1976 and 2001. The National Oil Spill Detection and Response Agency (NOSDRA) in Nigeria estimated that the crude oil spilled into the Niger Delta between 1976 and 1996 was more than 2.4 million barrels (The Guardian, 2010), of which 1.82 million (77\%) of the total spill was not recovered (Kadafa, 2012). The crude oil was spilled offshore, in swamps and on land (Uyigue and Agho, 2007). Some of the spills were caused by oil pipeline sabotage but the majority of oil spills were due to poor maintenance and monitoring by the oil companies (Aljazeera, 2012). In addition, Egwu (2012) also pointed out that some of the drilling facilities used by the oil companies are out-dated and the procedures employed for preventing oil spills are ineffective.

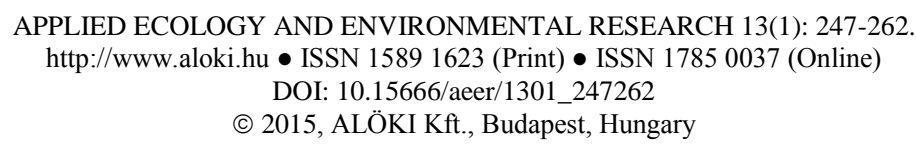


The incidence of oil spill accidents is higher on land than on water due to the extremely lengthy (thousands of kilometres long) pipelines which transport crude oil into storage tanks, rail tanks, road tanks and other facilities utilised in the export of liquid petroleum both locally and internationally (Owens, 2000). However, oil spill events on land are confined and often readily containable, while the infrequent oil spill accidents on water are often massive and devastating (Freedman, 1989). This is probably as a result of the greater difficulty in controlling the oil dispersion and spread.

Oil spill incidents are not only caused by pipeline vandalisation and accidents such as collision or explosion of supertankers or oil well blowout. There have been cases of oil spills initiated by natural disasters. For example, in 2005, Hurricane Katrina accounted for the spilling of a total of about 134,300 barrels of crude oil held by Bass Enterprises, Shell, Chevron and Murphy Oil Company in the United States (Llanos, 2005). The deliberate spill of liquid petroleum hydrocarbon into the environment may also occur due to war. Two examples were seen in 1991 during the Gulf war and in 2006 during the Israel-Lebanon crisis, releasing a total of 2-4 million barrels (Khordagui and AlAjmi, 1993) and 210,000 barrels (BBC, 2006) of crude oil respectively into the environment. However, the largest and most damaging pollution events usually involve a spill of petroleum from a disabled tanker or drill platform at sea or to a lesser extent from a blowout or a broken pipeline on land (Freedman, 1989).

It is imperative to note that the increasing demand for liquid petroleum may likely not reduce the number of oil spill occurrences. Therefore, oil spill accidents are prone to happen considering the enormous pressure on oil companies/drilling firms to make the petroleum product readily available for global consumption. Whenever there is an oil spill, shorelines, marine waters, groundwater, soils (including farmlands), lakes, rivers and creeks, stand the risk of being severely polluted, and if not controlled within a short time frame, may lead to long-term ecological devastation. Several oil spill remediation techniques for the clean-up of polluted terrestrial and marine environments have been established. However, most of them have been proven to be cost-ineffective and environmentally-unfriendly and hence, unsustainable. As a result, a control measure that will be swift, efficient and sustainable is a necessity. Therefore, attention has been shifted to the use of micro-organisms in cleaning-up both land and water oil spills. Liquid petroleum is composed of numerous hydrocarbon types and it has been observed that individual oil-degrading microbes have special preference for certain hydrocarbon types. Oil-degrading microbes also thrive best under certain environmental/nutritional conditions. This review is aimed at understanding the behaviour of oil-degrading microbes so as to improve the efficacy of microbial remediation of spilled petroleum.

The rate of biodegradation of petroleum hydrocarbonsvariesdepending on the composition and chemical nature of thepetroleum constituents. Crude oil is a liquid petroleum having thousands of hydrocarbon components. Each component has a unique chemical behaviour which makes it eithereasily biodegradable, quite difficult to digest or not degradable at all (The American Academy of Microbiology, 2011).

\section{The chemical composition and structure of Petroleum}

Petroleum hydrocarbon molecules can be grouped into four broad categories:

(a) Saturates (branched, unbranched and cyclic alkanes)

(b)Aromatics - ringed hydrocarbon molecules such as monocyclic aromatic hydrocarbons (MAHs) and polycyclic aromatic hydrocarbons (PAHs) 
(c)Resins (polar oil-surface structures dissolved in saturates and aromatics) (Speight, 1999)

(d)Asphalthenes (dark-brown amorphous solids colloidally dispersed in saturates and aromatics) (Balba et al., 1998; Speight, 1999; The American Academy of Microbiology, 2011).

In the structural arrangement of the four main hydrocarbon components of crude oil, saturates make up the outermost layer of the oil whilst asphalthenes constitute the innermost portion of the oil due to their heavier molecular weights.

PAH consist of about sixteen types that are priority pollutants (US EPA, 1993; Othman et al., 2011) but the following three have been the most studied: naphthalene, phenanthrene and pyrene. Alkene, another hydrocarbon component is mainly found in refined petroleum and not in crude petroleum because it is obtained by catalytic cracking (Matar, 1992). Light petroleum hydrocarbons such as gasoline, kerosene and diesel fuel are volatile and easily biodegradable (within days or weeks), so that they rarely persist in marine environments, although they may remain longer in terrestrial environments if buried in sediments, soils, groundwater, or marshes where oxygen levels are very low. However, heavy petroleum hydrocarbons are biodegraded slowly (The American Academy of Microbiology, 2011).Aromatics are more difficult to degrade than alkanes whilst asphalthenes may persist in the environment (The American Academy of Microbiology, 2011).

In general, lighter fractions of petroleum are more soluble in water than heavier ones; aromatics are much heavier than alkanes. Benzene, the lightest MAH has a solubility of $1780 \mathrm{~g} / \mathrm{m}^{3}$ whilst naphthalene, the lightest PAH has a solubility of $31 \mathrm{~g} / \mathrm{m}^{3}$ (Parker et al., 1971; Clark and MacLoed, 1977). Although alkanes are the most biodegradable petroleum hydrocarbons, those with 5-10 carbon atoms are toxic to most microorganisms by disrupting their lipid membranes (Bartha, 1986). Furthermore, petroleum hydrocarbons with 20-40 carbon atoms are hydrophobic at room temperature, which probably explains their slow biodegradation (Bartha and Atlas, 1977). Some bacteria, remarkably, produce waxes after degrading crude oil (Ishige et al., 2003).

According to van Hamme et al. (2003), the susceptibility of crude oil components to microbial degradation are in the following order: alkanes >light aromatics (MAHs such as benzene) >cycloalkanes > heavy aromatics (PAHs such as Phenanthrene)> asphalthenes. Resins are easily degraded naturally because they are light polar molecules (Spiecker et al., 2003).

PAHs are made up of more than one benzene ring and those that are made up of two or three cyclic rings such as naphthalene (two-ringed), phenanthrene (three-ringed) and anthracene (three-ringed) with molecular weights of $128 \mathrm{~g} / \mathrm{mol}, 178 \mathrm{~g} / \mathrm{mol}$ and $178 \mathrm{~g} / \mathrm{mol}$ respectively, are referred to as low molecular weight or light PAHs (Flores and Mestahoward, 2001). PAHs made up of four rings and above such as pyrene (fourringed), chrysenes (four-ringed), fluorenthene (five-ringed), benzo [a] pyrene (fiveringed) and coronenes (seven-ringed) with molecular weights of $202 \mathrm{~g} / \mathrm{mol}, 228 \mathrm{~g} / \mathrm{mol}$, $202 \mathrm{~g} / \mathrm{mol}, 252 \mathrm{~g} / \mathrm{mol}$ and $300 \mathrm{~g} / \mathrm{mol}$ respectively, are referred to as high molecular weight or heavy PAHs (Niederer et al., 1995; Kanaly and Harayama, 2000; Flores and Mestahoward, 2001; Schulz et al., 2012; MOE, 2013).

PAHs are common petroleum contaminants in the environment considered to be potentially mutagenic and carcinogenic (Boonchan et al., 2000; Mao et al., 2012). BCF (2013) reported that heavy PAHs such as Benzo [a] pyrene damage the DNA of living organisms (i.e. they are genotoxic) and are implicated in human breast cancer. This 
accounts to a high number of studies on the biodegradation of PAHs in order to safeguard the environment and biodiversity from severe long-term ecological and medical damage by oil spills. However, the focus has been on the biodegradation of light PAHs whilst very little research has been carried out on the biodegradation of heavy PAHs which have been found to be of medical importance.

Asphalthenes are considered to be highly resistant to biodegradation due to their heavy and viscous nature (The American Academy of Microbiology, 2011). Asphalthenes are very complex chemical structures made up of sulphur $(0.3-10.3 \%)$, nitrogen $(0.6-3.3 \%)$, oxygen $(0.3-4.8 \%)$ and trace amounts of metals such as iron, nickel and vanadium (Tavassoli et al., 2012). In addition, asphalthenes have the highest molecular weight of all hydrocarbon compounds in crude oil with values ranging from 600 to $3 \times 10^{5} \mathrm{~g} / \mathrm{mol}$ and from 1000 to $2 \times 10^{6} \mathrm{~g} / \mathrm{mol}$ (Speight and Moschopedis, 1981; Kawanaka et al., 1989; Flores and Mestahoward, 2001). This chemical complexity has rendered asphalthenes resistant to microbial attack and unfortunately few studies have been carried out to enhance the potential of biodegradation of asphalthenes.

\section{Factors influencing the microbial remediation of petroleum hydrocarbon}

Although it had been established that petroleum hydrocarbons were degraded by oileating micro-organisms since the 1940s (Zobell, 1946), the degree to which these processes occurred and the conditions that limited or enhanced biodegradation were not well understood until the 1960s (Le Petit and Barthelemy, 1968).

Oil-degrading microbes are able to break downcrude oil naturally (known as natural attenuation), however, this process is too slow to meet the demands of the environment due to the nutritional imbalance in the ecosystem (Le Petit and Barthelemy, 1968); hence, the need to optimise environmental/nutritional conditions in order to facilitate increasedmicrobial degradation of petroleum hydrocarbon.

Over the years, scientists have manipulated environmental indices in order to understand the factors that encourage microbial metabolism and hydrocarbon degradation, a knowledge which could help restore the environment to a pre-pollution state as early as possible. The main environmental/nutritional factors include the physical nature of the crude oil, the chemical nature of the crude oil, availability of nutrients, concentration of oxygen, water temperature, soil region and soil particle size, and competition from other micro-organisms (Boopathy, 2000; Fountoulakis et al., 2009; The American Academy of Microbiology, 2011).

\section{The physical nature of the spilled petroleum}

The physical nature of the spilled petroleum is a factor that affects both terrestrial and marine oil-spill bioremediation. A single large oil slick has a lesser surface area for oil-eating microbes to access compared to numerous small-sized oil slicks. As a result, the physical nature of the hydrocarbon pollutant can either slow down or hasten biodegradation. Also, heavy and viscous hydrocarbon compounds may prove to be recalcitrant as lighter hydrocarbons are quite easier for microbes to digest due to the higher rate of diffusion through the oil-water interface (The American Academy of Microbiology, 2011). 


\section{The chemical nature of the spilled petroleum}

The chemical nature of the spilled petroleum is determined by the particular hydrocarbon components of the liquid petroleum. Not all hydrocarbon components are biodegradable; some are degradable; some are degraded quickly while others are degraded slowly or not at all. In terrestrial and marine environments, the unbranched alkanes can be degraded within weeks but the branched alkanes and the multiple-ringed aromatic hydrocarbons are resistant to microbial degradation. Asphalthenes, on the other hand, are considered to be the most recalcitrant, thus, could accumulate in the environment (The American Academy of Microbiology, 2011).

\section{Availability of nutrients}

Similar to the nutritional needs of other organisms, oil-eating microbes also require nutrients for optimal growth and development. These nutrients are available in the natural environment but occur in low quantities. When there is an oil spill, the petroleum hydrocarbon provides carbon nutrients for the oil-eating bacteria to utilize, but the rate of degradation depends on the availability of other nutrients. The two most limiting nutrients observed are nitrogen and phosphorus which are incorporated into the cellular biomass and stimulate hydrocarbon metabolism (Prince, 1997; McKew et al., 2007a; Calvo et al., 2009). Other nutrients include sulphur and potassium (Evans et al., 2004). These nutrients are limiting factors for both land and water oil spill bioremediation.

\section{Water temperature}

The temperature of the surrounding water in which the oil is spilled determines the rate of hydrocarbon degradation whether it is fresh water or marine. Crude oil degradation is faster in warm water because the heat generated within the water body will further encourage the breakdown of the spilled petroleum through natural processes such as evaporation. This leaves the oil-degrading microbes with a smaller size of hydrocarbon pollutant to clean up (The American Academy of Microbiology, 2011). On the other hand, in cold environments such as the Arctic, oil degradation via natural processes is very slow and puts the microbes under more pressure to clean up the spilled petroleum.

The sub-zero temperature of water in this region causes the transport channels within the microbial cells to shut down or may even freeze the entire cytoplasm, thus, rendering most oleophilic microbes metabolically-inactive (Yang et al., 2009). However, some oleophilic microbes are cold-tolerant but are faced with the problem of freeze-thaw seasonal cycle thereby fluctuating between winter and summer, which limits the bioavailability of the spilled petroleum (Yang et al., 2009).

\section{The concentration of oxygen}

Oxygen is a gaseous requirement for most living organisms. Similarly, most oleophilic microbes are aerobes (such as Pseudomonas and Proteus) and a few others are anaerobes (such as Geobacter). As a result, environments with low oxygen concentration such as groundwater, deep soils and ocean sediments, have limited rates of hydrocarbon biodegradation compared to the open surfaces where oxygen is readily available for numerous oil-degrading aerobes to digest the pollutants. The presence of oxygen generally accelerates hydrocarbon metabolism (The American Academy of Microbiology, 2011). 


\section{The soil region and soil particle size}

The soil region and soil particle size are crucial factors limiting the biodegradation of petroleum hydrocarbon in the terrestrial environment. The subsurface soil regions include the vadose zone (unsaturated zone) and the groundwater zone (saturated zone). The surface soil region has the highest microbial population due to the regular input of organic material from plants and animals at the surface whilst the groundwater sediment zone has the lowest microbial population due to the anoxic condition (insufficient oxygen) which increases with soil depth (Adriaens and Hickey, 1993). Many anaerobes and few aerobes have been found to survive in the saturated zone (Boopathy, 2000).

In addition, the size of the soil particle determines the rate of soil permeability, which indirectly affects the rate of petroleum biodegradation. Fine soil particles such as clay have small interstitial spaces which make the soil impermeable, thus, retaining the spilled petroleum at the surface and reducing the bioavailability of microbial nutrients and oxygen. Coarse soil particles such as sand have large interstitial spaces which heavily drain hydrocarbon pollutants through the soil to the unsaturated and saturated zones, oxygen-deficient regions where the rate of biodegradation is very slow.

Moderately drained soils are the optimum requirements for the rapid bioremediation of oil-polluted soils. Soil $\mathrm{pH}$ has also been pointed out by the US EPA (2006) to influence bioremediation as it inhibits microbial activity and affects nutrient availability. The generally acceptable soil $\mathrm{pH}$ range for optimum bioremediation is 6-8 (US EPA, 2006).

\section{Competition from other micro-organisms}

The natural microbial community is composed of oil-degrading microbes that either cooperate together or compete with one another. Competition influences the rate of bioremediation and it could be inter-specific (between members of different species) or intra-specific (between members of the same species). Oil-degrading fungi could compete with oil-eating bacteria not only for the petroleum hydrocarbon but also for the limited nutrients available. As mentioned earlier, some antagonistic oleophilic bacteria have also been found to release metabolites that inhibit the growth and development of other oleophilic bacteria. The interdependence of microbial populations is a requirement for the successful application of bioremediation, which makes competition a limiting factor (The American Academy of Microbiology, 2011).

The appropriate manipulation of the aforementioned environmental and nutritional factors affecting the rate of bioremediation which could be helpful in improving the success of crude oil bioremediation strategies.

\section{Microbial remediation of petroleum hydrocarbons}

Microbial remediationhas been argued to be an efficient and sustainable oil spill clean-up technique by many authors (Trindade et al., 2005; Okoh and Trejo-Hernandez, 2006; Tyagi et al., 2011). It is a technology that utilizes the metabolic potential of micro-organisms such as bacteria, fungi and few protozoans (Watanabe, 2001) in degrading liquid petroleum spilled on terrestrial and marine environments, into harmless compounds. These oil-degrading microbes are not living in isolation, hence, referred to as microbial consortia. Of all the known oleophilic micro-organisms, bacteria are the most predominant in the environment (Leahy and Colwell, 1990). These oil-degrading bacteria are sometimes, referred to in literature, as hydrocarbonoclastic bacteria (HCB) 
(McKew et al., 2007a). Bacteria's reproductive potential and ubiquity may have made them the most preferred agent of hydrocarbon degradation for bioremediation.

In an oil remediation experiment using oil-utilising bacteria and protozoa as agents of degradation, it was observed that the population of the two agents initially increased which was then followed by a considerable decline in the population of bacteria (Accola, 1994). Acea and Alexander (1988) suggested that the sudden decline in bacterial population may have been "chiefly attributed to predation by protozoa"; although Huang et al. (1981) pointed out that the protozoans may be playing a useful role in stabilising the ecosystem by limiting the possible over-proliferation of bacteria. However, the presence of protozoa tends to disallow the establishment of oleophilic microbial consortia which may explain why not much research has been carried out on protozoa as agents of bioremediation.

The number of micro-organisms capable of utilizing the carbon in crude oil as their sole source of energy is relatively few compared to the general number of microbes available in the environment (Lebkowska et al., 1995). This is the reason it is important to have a good understanding of the available oil-degrading micro-organisms found both on land and water. Oil-eating micro-organisms produce enzymes which break down hydrocarbon compounds through single or multiple metabolic pathways.

The enzymes produced are incapable of breaking down all forms of hydrocarbon compounds; as a result, most oleophilic microbes are hydrocarbon-specific, although a few are physiologically-versatile and can degrade a wide-range of hydrocarbons (see Table 1). For example, toluene, an aromatic hydrocarbon, can be broken down via multiple metabolic pathways by the enzyme, toluene 2-monoxygenase (Ramos et al., 2011), produced by a toluene-degrading microbe (such as Rhodococcus spp.). The metabolic pathways include five aerobic pathways and at least one anaerobic pathway (Pazos et al., 2004). This biochemical diversity and hydrocarbon-specificity displayed by oleophilic microbes, if expressed in synergy by microbial consortia, will enhance bioremediation (Roling et al., 2002).

Table 1.The habitat and hydrocarbon-specificity of 40 oleophilic micro-organisms

\begin{tabular}{|l|l|l|l|}
\hline $\begin{array}{l}\text { Oleophilic } \\
\text { micro-organisms }\end{array}$ & $\begin{array}{l}\text { Bacteria/ } \\
\text { Fungi }\end{array}$ & Habitat & Hydrocarbon-specificity \\
\hline $\begin{array}{l}\text { Pseudomonas spp. } \\
\text { (Kanaly and Harayama, } \\
\text { 2000) }\end{array}$ & Bacterium & $\begin{array}{l}\text { Soil, river and } \\
\text { marine }\end{array}$ & $\begin{array}{l}\text { Benzene, toluene, ethylbenzene, xylene, } \\
\text { naphthalene, phenanthrene, kerosene and } \\
\text { diesel (Watanabe, 2001; Joshi and } \\
\text { Pandey, 2011) }\end{array}$ \\
\hline $\begin{array}{l}\text { Cycloclasticus spp. spp. } \\
\text { Alcanivorax }\end{array}$ & Bacterium & Soil, river and & $\begin{array}{l}\text { Alkanes (Yakimov et al., 1998; } \\
\text { marine }\end{array}$ \\
& & $\begin{array}{l}\text { Marayama et al., 1999; Chang et al., } \\
\text { 2000) }\end{array}$ \\
\hline
\end{tabular}


Macaulay: Understanding the behaviour of oil-degrading micro-organisms to enhance the microbial remediation of spilled petroleum -254 -

\begin{tabular}{|c|c|c|c|}
\hline Geobacter spp. & Bacterium & $\begin{array}{l}\text { Groundwater, } \\
\text { deep soil and } \\
\text { ocean } \\
\text { sediments }\end{array}$ & $\begin{array}{l}\text { Anaerobic breakdown of benzene } \\
\text { (Watanabe, 2001) }\end{array}$ \\
\hline Syntrophus spp. & Bacterium & $\begin{array}{l}\text { Groundwater, } \\
\text { deep soil and } \\
\text { ocean } \\
\text { sediments }\end{array}$ & $\begin{array}{l}\text { Anaerobic breakdown of hexadecane } \\
\text { (Zengler et al., 1999) }\end{array}$ \\
\hline Burkholderias spp. & Bacterium & Soil & $\begin{array}{l}\text { PAH (not specific) (Watanabe, 2001) } \\
\text { and xylene (Bacosa et al., 2012) }\end{array}$ \\
\hline Sphingomonas spp. & Bacterium & Soil & Pyrene (Ho et al., 2000) \\
\hline Mycobacterium spp. & Bacterium & Soil & $\begin{array}{l}\text { Benzo [a] pyrene and pyrene (Watanabe, } \\
\text { 2001) }\end{array}$ \\
\hline $\begin{array}{l}\text { Rhodococcus spp. (de } \\
\text { Carvalho et al., 2005) }\end{array}$ & Bacterium & $\begin{array}{l}\text { Soil, river and } \\
\text { marine }\end{array}$ & $\begin{array}{l}\text { Benzene, toluene, ethylbenzene, xylene, } \\
\text { anthracene and Benzo [a] pyrene } \\
\text { (Farhadian et al., 2008) }\end{array}$ \\
\hline $\begin{array}{l}\text { Ralstonia spp. (de } \\
\text { Carvalho et al., 2005) }\end{array}$ & Bacterium & $\begin{array}{l}\text { Soil, river and } \\
\text { marine }\end{array}$ & $\begin{array}{l}\text { Benzene, toluene, ethylbenzene and } \\
\text { xylene (Farhadian et al., 2008) }\end{array}$ \\
\hline Haemophilus spp. & Bacterium & $\begin{array}{l}\text { Soil, river and } \\
\text { marine }\end{array}$ & $\begin{array}{l}\text { Phenanthrene and pyrene (McKew et al., } \\
\text { 2007a) }\end{array}$ \\
\hline $\begin{array}{l}\text { Thalassolituus } \\
\text { oleivorans }\end{array}$ & Bacterium & Marine & $\begin{array}{l}\text { Phenanthrene and pyrene (McKew et al., } \\
\text { 2007a) }\end{array}$ \\
\hline Proteus spp. & Bacterium & Soil & $\begin{array}{l}\text { Xylene and diesel (Joshi and Pandey, } \\
\text { 2011) }\end{array}$ \\
\hline Bacillus spp. & Bacterium & Soil & $\begin{array}{l}\text { Toluene and diesel (Joshi and Pandey, } \\
\text { 2011) }\end{array}$ \\
\hline Mesorhizobium spp. & Bacterium & Soil & $\begin{array}{l}\text { Most PAH (not specific) (Mao et al., } \\
\text { 2012) }\end{array}$ \\
\hline Alcaligenes spp. & Bacterium & Soil & $\begin{array}{l}\text { Most PAH (not specific) (Mao et al., } \\
\text { 2012) }\end{array}$ \\
\hline Nocardia nova & Bacterium & Soil & $\begin{array}{l}\text { A wide spectrum of petroleum } \\
\text { hydrocarbon (Trindade, } 2002)\end{array}$ \\
\hline
\end{tabular}




\begin{tabular}{|c|c|c|c|}
\hline $\begin{array}{l}\text { Rhodotorula glutinis } \\
\text { var. dairenesis }\end{array}$ & Fungus & Soil & $\begin{array}{l}\text { A wide spectrum of petroleum } \\
\text { hydrocarbon (Trindade,2002) }\end{array}$ \\
\hline Planococcus spp. & Bacterium & Soil & $\begin{array}{l}\text { Light Arabian oil (Engelhardt et al., } \\
\text { 2001; Evans et al., 2004) }\end{array}$ \\
\hline Stenotrophomonas spp. & Bacterium & Soil & $\begin{array}{l}\text { PAH (not specific) (Vinas et al., 2002; } \\
\text { Vinas et al., 2005) }\end{array}$ \\
\hline Ochrobactrum spp. & Bacterium & Soil & $\begin{array}{l}\text { PAH (not specific) (Vinas et al., 2002; } \\
\text { Vinas et al., 2005) }\end{array}$ \\
\hline Pandorea spp. & Bacterium & Soil & $\begin{array}{l}\text { PAH (not specific) (Vinas et al., 2002; } \\
\text { Vinas et al., 2005) }\end{array}$ \\
\hline Labrys spp. & Bacterium & Soil & $\begin{array}{l}\text { PAH (not specific) (Vinas et al., 2002; } \\
\text { Vinas et al., 2005) }\end{array}$ \\
\hline Fusarium spp. & Fungus & Soil & $\begin{array}{l}\text { PAH (not specific) (Vinas et al., 2002; } \\
\text { Vinas et al., 2005) }\end{array}$ \\
\hline Fundibacter spp. & Bacterium & $\begin{array}{l}\text { Soil, river and } \\
\text { marine }\end{array}$ & $\begin{array}{l}\text { Alkanes (not specific) (Bruns and } \\
\text { Berthe-Corti, 1999) }\end{array}$ \\
\hline $\begin{array}{l}\text { Pseudomonas } \\
\text { paucimobilis }\end{array}$ & Bacterium & $\begin{array}{l}\text { Soil, river and } \\
\text { marine }\end{array}$ & Fluoranthene (Mueller et al., 1990) \\
\hline Micrococcus spp. & Bacterium & Soil/sludge & $\begin{array}{l}\text { Low molecular weight PAH (Othman et } \\
\text { al., 2011) }\end{array}$ \\
\hline Corynebacterium spp. & Bacterium & Soil/sludge & $\begin{array}{l}\text { Low molecular weight PAH (Othman et } \\
\text { al., 2011) }\end{array}$ \\
\hline Pediococcus spp. & Bacterium & Soil/sludge & $\begin{array}{l}\text { Low molecular weight PAH (Othman et } \\
\text { al., 2011) }\end{array}$ \\
\hline Sphingobacterium spp & Bacterium & Soil/sludge & $\begin{array}{l}\text { Low molecular weight PAH (Othman et } \\
\text { al., 2011) }\end{array}$ \\
\hline Tsukamurella spp. & Bacterium & Soil/sludge & $\begin{array}{l}\text { Low molecular weight PAH (Othman et } \\
\text { al., 2011) }\end{array}$ \\
\hline Phanerochaete spp. & Fungus & Soil & PAH (not specific) (Li et al., 2009) \\
\hline Chrysosporium spp. & Fungus & Soil & PAH (not specific) (Li et al., 2009) \\
\hline Cuuninghamella spp. & Fungus & Soil & PAH (not specific) (Li et al., 2009) \\
\hline Alternaria alternate & Fungus & Soil & PAH (not specific) (Li et al., 2009) \\
\hline $\begin{array}{l}\text { Penicillium } \\
\text { chrysogenum }\end{array}$ & Fungus & Soil & PAH (not specific) (Li et al., 2009) \\
\hline Aspergillus niger & Fungus & Soil & PAH (not specific) (Li et al., 2009) \\
\hline Zoogloea spp. & Bacterium & Soil & PAH (not specific) (Li et al., 2009) \\
\hline
\end{tabular}




\begin{tabular}{|l|l|l|l|}
\hline Flavobacterium spp. & Bacterium & Soil & PAH (not specific) (Li et al., 2009) \\
\hline Cupriavidus spp. & Bacterium & Soil; marine & Decane (Bacosa et al., 2012) \\
\hline
\end{tabular}

Besides the catabolic potential of oil-degrading microbes, other strategies have been adopted by these microbes to enhance the detoxification of pollutants, such as the modification of their cell membrane to preserve their structural integrity when in contact with pollutants (de Carvalho et al., 2005); the production of surface active compounds known as biosurfactants which helps to partially weather the pollutant, thereby, rendering it vulnerable to microbial degradation (Ron and Rosenberg, 2002) and the release of toxic pollutants from within the microbe's protoplasm via efflux pumps, active transporters located in the cytoplasmic membrane (van Hamme et al., 2003).

Competition amongst oil-degrading micro-organisms has also been observed. Some oleophilic microbial consortia develop synergistic relationships whilst few others show competitive relationships. For example, Cycloclasticus and Alcanivorax borkumensis show a synergistic association because A. borkumensis produces an extracellular lipid biosurfactant which render PAHs readily available for digestion by Cycloclasticus and the competition for hydrocarbon resources is absent because $A$. borkumensis feeds on another hydrocarbon (alkanes) (Yakimov et al., 1998; McKew et al., 2007a). However, Thalassolituus exhibits an antagonistic relationship with other oil-eating bacteria by producing a metabolite which inhibits their growth and development (Yakimov et al., 2005).

It has been well established that the presence of microbial consortia rather than individual microbes will enhance bioremediation; therefore, the antagonistic potential of some oil-degrading microbes could limit the efficiency of microbial remediation. The activities of these antagonistic oil-degrading bacteria have to be controlled in order to encourage the continued development of viable oil-degrading microbial consortia.

\section{Conclusion}

The behaviour of oil-degrading micro-organisms towards spilled petroleum has beeninvestigated. Oil-degrading microbes modify their cell membranes, produce biosurfactants and eject toxic pollutants from their protoplasm in order to survive petroleum-contaminated areas. The hydrocarbon-specificity displayed by oil-degrading micro-organisms is as a result of the metabolic pathway individually utilized. Microbes capable of utilizing multiple biochemical pathways find it easy to degrade a wider range of hydrocarbon compounds. Of all the four basic components of petroleum, asphalthene is the most recalcitrant to microbial degradation due to its chemical complexity. Also, it appears that there are more oil-degrading aerobes than anaerobes, and most of these aerobes are terrestrial in habit. The study of the behaviour and factors influencing the microbial metabolism of hydrocarbon compounds will ultimately aid the understanding of how best these factors and elements can be manipulated to achieve an accelerated microbial degradation of spilled petroleum world-wide. 


\section{REFERENCES}

[1] Accola, B. (1994): Population responses of protozoa, heterotrophic bacteria and hydrocarbon degrading bacteria to crude oil stress. - PhD thesis. Department of Biological Sciences, University of Alaska, Fairbanks (UAF), United States. 25th March, 1994.

[2] Acea, M.J., Alexander, M. (1988): Growth and survival of bacteria introduced into carbon-amended soil. - SoilBiology and Biochemistry 20 (5): 703-709.

[3] Adriaens, P., Hickey, W.J. (1993): Biotechnology for the treatment of hazardous waste. D.L., Stone (Ed.). Lewis Publications. Ann Arbor, Michigan, United States. Pp. 97-120.

[4] Aljazeera (2012): Shell could face huge fine for Nigeria spill. - Aljazeera. http://www.aljazeera.com/news/africa/2012/07/2012717174836875241.html. Uploaded on the 17th July, 2012. Accessed on the 27th February, 2013.

[5] Anisuddin, S., Al-Hashar, N., Tasheen, S. (2005): Prevention of oil spill in seawater using locally available materials. -Arabian Journal of Science and Engineering 30(2B): 143-152.

[6] Bacosa, H.P., Suto, K., Inoue, C. (2012): Bacterial community dynamics during the preferential degradation of aromatic hydrocarbons by a microbial consortium. - Internal Biodeterioration and Biodegradation 74: 109-115.

[7] Balba, M.T., Al-Awadhi, N., Al-Daher, R. (1998): Bioremediation of oil-contaminated soil: Microbiological methods for feasibility assessment and field evaluation. - Journal of Microbiological Methods 32:155-164.

[8] Bartha, R., Atlas, R.M. (1977): The microbiology of aquatic oil spills. - Advances in Applied Microbiology 22:225-266.

[9] Bartha, R. (1986): Biotechnology of petroleum pollutant biodegradation.- Microbial Ecology 12:155-172.

[10] BBC (2006): Environmental crisis in Lebanon. - BBC News. http://www.bbc.co.uk/news/world. Uploaded on the 31st July, 2006. Accessed on the 27th February, 2013.

[11] BCF (2013): Polycyclic aromatic hydrocarbons (PAHs). - Breast Cancer Fund (BCF). http://www.breastcancerfund.org/clear-sience/chemicals-glossary/polycyclic-aromatichydrocarbons.html. Accessed on the 4th July, 2013.

[12] Boonchan, S., Britz, M.L., Stanley, G.A. (2000): Degradation and mineralisation of highmolecular-weight polycyclic aromatic hydrocarbons by defined fungal-bacterial cocultures. -Applied and Environmental Microbiology, 66: 1007-1019.

[13] Boopathy, R. (2000): Factors limiting bioremediation technologies. - Bioresource Technology 74: 63-67.

[14] Bruns, A., Berthe-Corti, L. (1999): Fundibacter jadensis gen. nov. sp. nov. A new slightly halophilic bacterium, isolated from internal sediments. - International Journal of Systematic Bacteriology 49: 441-448.

[15] Calvo, C., Manzanera, M., Silva-Castro, G.A., Uad, I., Gonzalez-Lopez, J. (2009): Application of bioemulsifiers in soil oil bioremediation processes: Future prospects. Science of Total Environment 407: 3634-3640.

[16] Chang, Y.J., Stephen, J.R., Richter, A.P., Venosa, A.D., Bruggemann, J., MacNaughton, S.J., Kowalchuk, G.A., Haines, J.R., Kline, E., White, D.C. (2000): Phylogenetic analysis of aerobic freshwater and marine enrichment cultures efficient in hydrocarbon degradation: effect of profiling method.- Journal of Microbial Methods 40:19-31.

[17] Clark, R.C., MacLoed, W.D. (1977): Inputs, transport mechanisms and observed concentrations of petroleum in the marine environment. - In Effects of petroleum on Arctic and Subarctic marine environments and organisms. D.C. Malins (Ed.), Volume 1, pp. 91-224. Academic Press, New York, United States.

[18] de Carvalho, C.C.C.R., da Fonseca, M.M.R. (2005): The remarkable Rhodococcus erythropolis. - Applied Microbiology and Biotechnology 67: 715-726.

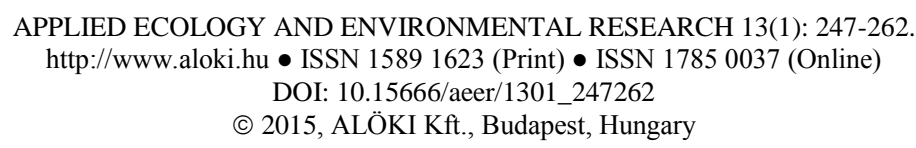


[19] Egwu, S.A. (2012): Oil spill control and management. - Petroleum Technology Development Journal 1: 1-6.

[20] Engelhardt, M.A., Daly, K., Swannell, R.P., Head, I.M. (2001): Isolation and characterization of a novel hydrocarbon-degrading gram-positive bacterium isolated from inter-tidal beach sediment and description of Planococcus alkanoclasticus sp. nov. Journal of Applied Microbiology 90: 237-247.

[21] Evans, F.F., Rosando, A.S., Sebastian, G.V., Casella, R., Machado, P.L.O.A., Holmstrom, C., Kjelleberg, S., van Elsas, J.D., Seldin, L. (2004): Impact of oil contamination and biostimulation on the diversity of indigenous bacterial communities in soil microcosms. - FEMS Microbiology and Ecology 49: 295-305.

[22] Farhadian, M., Vachelard, C. Duchez, D., Larroche, C. (2008): In situ bioremediation of monoaromatic pollutants in ground water: A review. - Bioresource Technology 99: 52965308.

[23] Flores, G.P., Mestahoward, A. (2001): Petroleum asphalthenes: generated problematic and possible biodegradation mechanisms. - Review in Latin-American Microbiology 43: 143-150.

[24] Fountoulakis, M.S., Terzakis, S., Kalogerakis, N., Manios, T. (2009): Removal of polycyclic aromatic hydrocarbons and linear alkylbenzene sulfonates from domestic wastewater in pilot constructed wetlands and gravel filter. - Ecological Engineering 35: 1702-1709.

[25] Freedman, B. (1989): Environmental Ecology: The impacts of pollution and other stresses on ecosystem structure and function. - Academic Press, San Diego, California, United States. Pp. 138-158.

[26] Harayama, S., Kishira, H., Kasai, Y., Shutsubo, K. (1999): Petroleum biodegradation in marine environments. - Journal of Molecular Microbiology and Biotechnology 1: 63-70.

[27] Ho, Y., Jackson, M., Yang, Y., Mueller, J.G., Pritchard, P.H. (2000): Characterisation of fluoranthene and pyrene degrading bacteria isolated from PAH contaminated soils and sediments and comparison of several Sphingomonas spp. - Journal of Industrial Microbiology 2:100-112.

[28] Huang, T., Chang, M., Alexander, M. (1981). Effect of protozoa on the bacterial degradation of an aromatic compound. - Applied and Environmental Microbiology 41 (1): 229-232.

[29] Ishige, T., Tani, A., Sakai, Y., Kato, N. (2003): Wax ester production by bacteria. Current Opinion in Microbiology 6: 244-250.

[30] Joshi, P.A., Pandey, G.B. (2011): Screening of petroleum degrading bacteria from cow dung. - Research Journal of Agricultural Sciences 2(1): 69-71.

[31] Kadafa, A.A. (2012): Oil exploration and spillage in the Niger Delta of Nigeria. - Civil and Environmental Research 2 (3): 38-51.

[32] Kawanaka, S., Leontaritis, K.J., Park, S.J., Mansoori, G.A. (1989): Thermodynamics and colloidal models of asphalthene flocculation. - In: ACS symposium series, oil field chemistry enhanced recovery and production stimulation. ACS Washington DC., Pp. 450458.

[33] Khordagui, H., Al-Ajmi, D. (1993): Environmental impact of the Gulf war: An integrated preliminary assessment. - Environmental Management 17 (4): 557-562.

[34] Leahy, J.G., Colwell, R.R. (1990): Microbial degradation of hydrocarbons in the environment. - Microbiology Review 54 (3): 305-315.

[35] Lebkowska, M., Karwowska, E., Miaskiewicz, E. (1995): Isolation and identification of bacteria from petroleum derivatives contaminated soil. - Acta Microbiologica Polonica 44:297-303.

[36] Le Petit, J., Barthelemy, M.H. (1968): Optimization of bioremediation. - In: Remediation of petroleum contaminated soils: Biological, physical and chemical processes. Environmental Science Engineering, Lewis publishers, United States. Pp. 297-306. 
[37] Li, X.J., Lin, X., Li, P.J., Liu, W., Wang, L., Ma, F., Chukwuka, K.S. (2009): Biodegradation of the low concentration of polycyclic aromatic hydrocarbons in soil by microbial consortium during incubation. - Journal of Hazardous Materials 172: 601-605.

[38] Llanos, M. (2005): 44 oil spills found in southwest Louisiana. - Hurricanes Archive on NBCNews.com. http://www.nbcnews.com/id/9365607/ns/us_newskatrina_the_long_road_back/t/oil-spills-found-southeast-louisiana/\#.Ue_f0I21GLg. Uploaded on the 19th September, 2005. Accessed on the 4th March, 2013.

[39] Mao, J., Luo,Y., Teng, Y., Li, Z. (2012): Bioremediation of polycyclic aromatic hydrocarbon-contaminated soil by a bacterial consortium and associated microbial community changes. - International Biodeterioration and Biodegradation 70: 141-147.

[40] Matar, M.S. (1992): Characteristics of crude oils and properties of petroleum products. In Petroleum economics and engineering, H.K., Abdel-Aal, B.A, Bakr and M.A., AlSahlawi (Eds.). 2nd edition, Marcel Dekker Inc., New York. Pp. 33-54.

[41] McKew, B.A., Coulon, F., Osborn, A.M., Timmis, K.N., McGenity, T.J. (2007): Determining the identity and roles of oil-metabolising marine bacteria from the Thames Estuary, UK. - Environmental Microbiology 9: 165-176.

[42] MOE (2013): PAHs and their characteristics. - Ministry of Environment (MOE), British Columbia, Canada. http://www.env.gov.bc.ca/wat/wq/BCguidelines/pahs/pahs-01.htm. Accessed on the 27th July, 2013.

[43] Mueller, J.G., Chapman, P.J., Pritchard, P.H. (1990): Isolation and characterization of fluoranthene utilizing strain of Pseudomonas paucimobilis. - Journal of Applied and Environmental Microbiology 56:1079-1086.

[44] Niederer, M., Maschka-Selig, A., Hohl. C. (1995): Monitoring polycyclic aromatic hydrocarbons (PAHs) and heavy metals in urban soil, compost and vegetation. Environmental Science and Pollution Research 2 (2): 84.

[45] Okoh, A.I., Trejo-Hernandez, M.R. (2006): Remediation of petroleum hydrocarbon polluted systems: Exploiting the bioremediation strategies. - African Journal of Biotechnology 5 (25): 2520-2525.

[46] Othman, N., Irwan, J.M., Hussain, N., Abdul-Talib, S. (2011): Bioremediation a potential approach for soil contaminated with polycyclic aromatic hydrocarbons: An overview. - International Journal of Sustainable Construction Engineering and Technology 2 (2): 48-53.

[47] Owens, E.H. (2000): Response to spills on land. http://www.interspill.com/previousevents/2000/30-Nov/pdf/owens.pdf. Updated 30th November, 2000. Accessed on the 4th March, 2013.

[48] Parker, C.A., Freegrade, M., Hatchard, C.G. (1971): The effect of some chemical and biological factors on the degradation of crude oil at sea. - In: Water pollution by oil, pp. 237-244. Institute of Petroleum, London, United Kingdom.

[49] Pazos, F., Guijas, D., Valencia, A., de Lorenzo, V. (2004): MetaRouter: Bioinformatics for bioremediation. - Nucleic Acid Research 33: 588-592.

[50] Poland, J.S, Riddle, M.J., Zeeb, B.A. (2003): Contaminants in the Arctic and the Antarctic: A comparison of sources, impacts and remediation options. - Polar Record 39: 369-383.

[51] Prince, R.C. (1997): Bioremediation of marine oil spills. - Trends in Biotechnology 15: 158-160.

[52] Ramos, J.L., Marques, S., Dillewijn, van. P., Espinosa-Urgel, M., Segura, A., Duque, E., Krell, T., Ramos-Gonzalez, M-I., Bursakov, S., Roca, A., Solano, J., Fernandez, M., Niqui, J.L., Pizarro-Tobias, P., Wittich, R-M. (2011): Laboratory research aimed at closing the gaps in microbial bioremediation. - Trends in Biotechnology 29 (12): 641647.

[53] Roling, W.F.M., Milner, M.G., Jones, D.M., Lee, K., Daniel, F., Swannell, R.J.P., Head, I.M. (2002): Robust hydrocarbon degradation and dynamics of bacterial communities 
during nutrient-enhanced oil spill bioremediation. - Applied Environmental Microbiology 68 (11): 5537.

[54] Ron, E.Z., Rosenberg, E. (2002): Biosurfactants and oil bioremediation. - Current Opinions in Biotechnology, 13: 249-252.

[55] Schulz, C.M., Ruthenschor, A., Fritz, H., Kuipers, J., Oostdijk, J., Erwine, M. (2012): Different stationary phases for PAH analysis. - Food Quality and Safety. http://www.foodquality.com/details/article/1480161/different_stationary_phases_for_PA H_Analysis.html?tzcheck=1. Uploaded Feburary/March 2012. Accessed on the 27th July, 2013.

[56] Speight, J.G. (1999): The chemical and physical structure of petroleum: effects on recovery operations. - Journal of Petroleum Science and Engineering 22: 3-15.

[57] Speight, J.G., Moschopedis, S.E. (1981): On the molecular nature petroleum asphalthenes. - In Chemistry of asphalthenes. J.W., Bunger and N.C., Li (Eds.). American Chemical Society, Pp.1-15.

[58] Spiecker, P.M., Gawrys, K.L., Trail, C.B., Kilpatrick, P.K. (2003): Effects of petroleum resins on asphalthene aggregation and water-in-oil emulsion formation. - Colloids and surfaces A: Physicochemical Engineering Aspects 220: 9-27.

[59] Tavassoli, T., Mousavi, S.M., Shojaosadati, S.A., Salehizadeh, H. (2012): Asphalthene biodegradation using micro-organisms isolated from oil samples. - Fuel 93: 142-148.

[60] The American Academy of Microbiology (2011): Microbes and oil spills. - FAQseries. http://www.dfo-mpo.gc.ca/science/publications/microbes/pdf/microbes-eng.pdf. Accessed on the 20th Feburary, 2013.

[61] The Guardian (2010): Nigeria's agony dwarfs the Gulf oil spill: The US and Europe ignore it. - Environment oil spills section, J. Vidal (Ed.). http://www.guardian.co.uk/world/2010/may/30/oil-spills-nigeria-niger-delta-shell. Uploaded on the 30th May, 2010. Accessed on the 27th February, 2013.

[62] Trindade, P.V.O. (2002): Evaluation of techniques for bioaugmentation and biostimulation treatment of hydrocarbon contaminated soil from oil. - M.Sc.thesis, Universidade Federal do Rio de Janeiro, Escola de Quimica, do Rio de Janeiro, Brazil.

[63] Trindade, P.V.O, Sobral, L.G., Rizzo, A.C.L., Leite, S.G.F., Soriano, A.U. (2005): Bioremediation of a weathered and a recently oil-contaminated soils from Brazil: A comparison study. - Chemosphere 58: 515-522.

[64] Tyagi, M., Da Fonseca, M.M.R., De Carvalho, C.C.C.R. (2011): Bioaugmentation and biostimulation strategies to improve the effectiveness of bioremediation processes. Biodegradation 22: 231-241.

[65] UNDP (2006): Niger Delta human development report. - United Nations Development Programme (UNDP). http://hdr.undp.org/en/reports/nationalreports/africa/nigeria/html. Accessed on the 27th February, 2013.

[66] US EPA (1993): Selecting remediation technologies for contaminated sediment. - United States Environmental Protection Agency (US EPA), Washington DC., United States. EPA-823-B93-001.

[67] US EPA (2006): A citizen's guide to bioremediation. - United States Environmental Protection Agency (US EPA), Washington DC., United States. http://www.epa.gov/tio/download/citizens/bioremediation.pdf. Uploaded on the 24th November, 2006. Accessed on the 8th April, 2013.

[68] Uyigue, E., Agho, M. (2007): Coping with climate change and environmental degradation in the Niger Delta of Southern Nigeria. - Community Research and Development Centre Nigeria (CREDC), Edo state, http://priceofoil.org/content/uploads/2007/06/07.06.11\%20\%20Climate_Niger_Delta.pdf. Accessed on the 28th February, 2013.

[69] van Hamme, J.D., Singh, A., Ward, O.P. (2003): Recent advances in petroleum microbiology. - Microbiology and Molecular Biology Review 67(4): 503. 
[70] Vinas, M., Grifoll, M., Sabate, J., Solanas, A.M. (2002): Biodegradation of a crude oil by three microbial consortia of different origins and metabolic capabilities. - Journal of Industrial Microbiology and Biotechnology 28: 252-260.

[71] Vinas, M., Sabate, J., Espuny, M.J., Solanas, A.M. (2005): Bacterial community dynamics and polycyclic aromatic hydrocarbon degradation during bioremediation of heavily creosote-contaminated soil. - Applied and Environmental Microbiology 71 (11): 7008-7018.

[72] Watanabe, K. (2001): Micro-organisms relevant to bioremediation. - Current Option in Biotechnology 12 (3): 237-241.

[73] Yakimov, M.M., Golyshin, P.N., Lang, S., Moore, E.R.B., Abraham, W.R., Lunsdorf, H., Timmis, K.N. (1998):Alcanivorax borkumensis gen. nov., sp. nov., a new hydrocarbondegrading and surfactant-producing marine bacterium. - International Journal of Systematic Bacteriology 48:339-348.

[74] Yakimov, M.M., Denaro, R., Genovese, M., Cappello, S., D’Auria, G., Chernikova, T.N., Timmis, K.N., Golyshin, P.N., Giluliano, L. (2005): Natural microbial diversity in superficial sediments of Milazzo Harbor (Sicily) and community successions during microcosm enrichment with various hydrocarbons. - Environmental Microbiology 7: 1426-1441.

[75] Yang, S.Z., Jin, H., Wei, Z. (2009): Bioremediation of oil spills in cold environments: A review. - Pedosphere 19: 371-381.

[76] Zengler, K., Richnow, H.H., Rossello-Mora, R., Michaelis, W., Widdel, F. (1999): Methane formation from long-chain alkanes by anaerobic micro-organisms. - Nature 401: 266-269.

[77] Zobell, C.E. (1946): Action of micro-organisms on hydrocarbons. - Bacteriology Reviews 10: 1-49. 